Uniwersytet im. Adama Mickiewicza w Poznaniu

\title{
Ochrona wizerunku w dobie tabloidyzacji mediów
}

$\mathrm{O}$ bserwując współczesne rynki medialne, powszechnie dostrzegalnym zjawiskiem jest dominacja tabloidów, które odnoszą sukcesy czytelnicze i ekonomiczne. Wyjaśnić w pierwszej kolejności należy, iż pojęcie to wywodzi się od formatu prasy, która powstała jeszcze na przełomie XIX i XX w., choć genezy tego pojęcie można doszukiwać się znacznie wcześniej ${ }^{1}$. Zapewne skuteczność i efektywność ekonomiczna takich ofert medialnych decyduje, iż dostrzega się proces szerszy, polegający na ,zainfekowaniu wirusem” tabloidów wszelkich form przekazu medialnego, a zatem nie tylko gazet, ale także mediów elektronicznych. I to w tym kontekście mówi się o tabloidyzacji mediów, co oznaczać miałoby transformację tradycyjnych ,szlachetnych" formatów medialnych, w kierunku środków społecznego przekazu charakteryzujących się dominacją tematów wzbudzających szerokie zainteresowanie (rozrywka, skandale wśród celebrytów), epatujące seksem i przemocą, oraz - co szczególnie istotne z punktu widzenia niniejszego opracowania - bogato ilustrowane ${ }^{2}$. Przedmiotem niniejszego opracowania jest próba wskazania reguł prawnych odnoszących się do ochrony wizerunku w kontekście powyżej wskazanych tendencji.

$\mathrm{Na}$ wstępie wypada rozstrzygnąć kwestię oczywistą na pierwszy rzut oka, a jednak wzbudzającą pewne wątpliwości, skoro musiał je rozwiać Sąd Najwyższy. Mianowicie, chodzi o ustalenie czy tabloidy należy zaliczać do kategorii prasy. Ten rodzaj działalności prasowej jest nie tylko krytykowany i to również ze strony części środowiska dziennikarskiego, ale niekiedy wręcz odmawia się przyznania takim formom aktywności statusu prasy, a osobom tam publikującym przymiotu dziennikarza. Tym

1 Patrz szerzej na ten temat Z. Bauer, Twój głos w Twoim domu: cztery typy tabloidyzacji, http://www.slideshare.net/52zbigi/tabloidyzacja, data wejścia 8.06.2013 r. Autor przedstawia różne koncepcje tego pojęcia.

2 Ponadto formy prezentacji materiałów prasowych są krótsze, a co za tym idzie zwykle w sposób uproszczony prezentujące opisywane zagadnienia, często przekraczające granice dobrego smaku. 
niemniej SN wyroku z dnia 29 maja 2008 r. ${ }^{3}$ jednoznacznie przesądził, „,iż - mimo ogromnej krytyki - tabloidy należy zaliczać do kategorii prasy, jeżeli spełniają przesłanki określone w art. 7 ust. 1 pkt 1 ustawy z dnia 1984 r. prawo prasowe"4. W uzasadnieniu tego wyroku Sądu Najwyższego podkreślono, że ,prasą - a co za tym idzie środkami masowego komunikowania - są także tytuły przeznaczone dla masowego, niewyrobionego odbiorcy, schlebiające najprymitywniejszym gustom, zaspokajające prostacką żądzę sensacji. W tym stanie rzeczy tzw. tabloidy są prasą (a więc także środkami masowego komunikowania w rozumieniu art. $212 \S 2$ k.k.). Ani Kodeks karny, ani Prawo prasowe, określając prawa i obowiązki dziennikarzy (art. 10-12 pr.pr.), ani żaden inny akt prawny nie czyni dystynkcji między standardami, jakie muszą spełniać poważne tytuły prasowe, adresowane do wyrobionego, wykształconego czytelnika, a tymi wymogami, którym muszą odpowiadać pisma popularne, szukające sensacji w tym także tabloidy"5.

Wyjaśnienia wymaga także pojęcie wizerunku. W doktrynie wyróżnia się cztery odmienne pojęcia, a mianowicie obraz fizyczny, wizerunek, portret i egzemplarz ${ }^{6}$. Wedle tej typologii, obraz fizyczny to wygląd człowieka, czyli dostrzegalne cechy człowieka ${ }^{7}$. Wizerunek to z kolei inaczej podobizna, a więc projekcja obrazu fizycznego możliwa do rozpowszechniania. Wreszcie - wedle tej koncepcji - portret to utwór prezentujący daną osobę ${ }^{8}$. Przy takim założeniu, należy wyraźnie odróżniać portret od nośnika, na którym został utrwalony, a więc egzemplarza 9 .

3 Por. wyrok Sądu Najwyższego z dnia 29 maja 2008 r. o sygn. akt II KK 12/08, LEX nr 448953.

4 Ustawa z dnia 26 stycznia 1984 r. Prawo prasowe, Dz. U. Nr 5, poz. 24 z późn. zm., dalej jako pr.pr.

5 Wyrok SN z dnia 29 maja 2008 r., sygn. II KK 12/08.

6 T. Grzeszak, w: System prawa prywatnego, t. 13; Prawo autorskie, red. J. Barta, wyd. II, Warszawa, s. 539-540; P. Ślęzak, Ochrona prawa do wizerunku, Katowice 2009, s. 11.

7 E. Wojnicka, Prawo do wizerunku w ustawodawstwie polskim, „ZNUJ PWiOWI”, Kraków 1990, z. 56, s. 107.

8 P. Ślęzak, op. cit., s. 13. Autor wymienia także jako odrębną kategorię personę, czyli możliwość sprzeciwiania się w reklamach różnego typu skojarzeniom $\mathrm{z}$ daną osobą. Jednocześnie uznaje, że nie jest to odrębne z dóbr osobistych.

9 Ibidem, inaczej E. Wojnicka, op. cit., s. 107, z kolei jeszcze inni autorzy stoją na stanowisku, iż jest to połączenie dobra osobistego i nośnika. Tak K. Stefaniuk, Naruszenie prawa do wizerunku przez rozpowszechnianie podobizny, „Państwo i Prawo" 1970, nr 1, s. 64-65. 
Abstrahując od powyższej typologii, trzeba jednak zauważyć, iż dość powszechnie używa się określenia wizerunek na określenie wszystkich powyższych kontekstów.

Dlatego też zauważa się, że wizerunek jest to zespół wszystkich cech zewnętrznych charakterystycznych dla danej jednostki, w szczególności twarz ${ }^{10}$, ale może to być cała sylwetka danej osoby, jak również elementy dodane takie jak fryzura, makijaż, strój, sposób poruszania się ${ }^{11}$, ewentualnie inne dodatkowe okoliczności ułatwiające rozpoznanie danej osoby $^{12}$. Dlatego też zdaniem niektórych autorów, również obraz sylwetki przedstawionej na fotografii od tyłu, ale $\mathrm{z}$ charakterystycznymi cechami np. kurtką i torbą, może identyfikować dostarczenie daną osobę ${ }^{13}$. Wskazanie w czasopiśmie osoby pozornie zamaskowanej, a w rzeczywistości rozpoznawalnej, może stygmatyzować ją oraz najbliższe jej osoby i powodować ostracyzm w kręgu społecznym, z którym pokrzywdzony wiąże swoje życie, aktywność społeczną oraz zawodową ${ }^{14}$.

10 J. Błeszyński, Prawo autorskie, Warszawa 1988, s. 155; J. Barta, R. Markiewicz, Wokół prawa do wizerunku, „ZNUJ PWiOWI”, Kraków 2002, z. 80, s. 12.

11 P. Ślęzak, op. cit., s. 12.

12 J. Sieńczyło-Chlabicz, Przedmiot, podmiot i charakter prawa do wizerunku, „Przegląd Ustawodawstwa Gospodarczego” 2003, nr 8, s. 20.

13 J. Barta, R. Markiewicz, w: Prawo mediów, red. idem, A. Matlak, Warszawa 2005, s. 452. Jak podkreślił Sąd Apelacyjny w Krakowie w wyroku z 7.02.1995 r. wizerunek to ogół zewnętrznych cech. Por. Wyrok Sądu Apelacyjnego w Krakowie z 7.02.1995 r., sygn. akt I ACr 697/94. W tym samym orzeczeniu podkreślono, że - karykatura scenicznego wyglądu aktora (maska artystyczna - w tym przypadku chodziło o Genowefę Pigwę) - zasługuje na ochronę.

14 Wyrok SN z 24.01.2008 r. I CSK 319/07. Artykuł poprzedzony był na stronie tytułowej tzw. zwiastunem pt. Skandal Sad uwolnit pedofila, a w jego treści znajdowała się informacja, że niebezpiecznym pedofilem, zwolnionym z aresztu jest K. D., dziennikarz, dyrektor generalny wydawnictwa będącego właścicielem „P”.

Po zatrzymaniu K. D. dziennikarze „F” przeprowadzili z powodem AC, który był redaktorem w miejscowej gazecie rozmowę o zdarzeniu i funkcji zatrzymanego, robili zdjęcia i uzyskali zgodę powoda na opublikowanie uzyskanych informacji. Sąd ustalił, że podczas przygotowania materiału do druku doszło do pomyłki i zamiast fotografii dyrektora wydawnictwa skierowano do druku fotografię powoda pozwalającą na jego rozpoznanie, mimo przesłonięcia oczu czarnym prostokątem.

Następnego dnia obok tytułu Sędzia puścit pedofila ukazało się w „F” zdjęcie K. D. i - na tej samej stronie - niewielka wzmianka zatytułowana „F. przeprasza” oraz niemaskowane zdjęcie powoda i stwierdzenie, że redakcja przeprasza S. P. redaktora naczelnego „Przeglądu” za omyłkowe umieszczenie jego zdjęcia w artykule z poprzedniego dnia. 
Zdaniem niektórych autorów wizerunek to także głos (tzw. wizerunek dźwiękowy ${ }^{15}$ ), charakterystyczne powiedzonka, gesty, sposób poruszania się, wirtualny sobowtór. Nie będą natomiast traktowane jak wizerunek miejsca i rzeczy kojarzone z określoną osobą, takie jak dom, mieszkanie, zwierzę np. pies. Jak często podkreśla się, inna wykładnia niż wyżej zaprezentowana ograniczałaby swobodę fotografowania. Wyjaśnić tu trzeba, że odrębnym od wizerunku dobrem osobistym będzie także tzw.

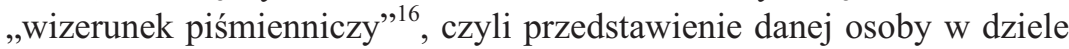
literackim.

Jak z powyższego wynika, koniecznym warunkiem ochrony wizerunku i kryterium rozstrzygania czy doszło do działań niezgodnych z prawem, jest przesłanka rozpoznawalności danej osoby. Choć w judykaturze nie ma w tym zakresie ujednoliconej linii orzeczniczej ${ }^{17}$, podzielić należy te stanowiska i poglądy doktryny ${ }^{18}$, w myśl których, nie ma jednak wymogu, aby taka możliwość identyfikacji dotyczyła wszystkich, wystarczy, że identyfikacji danej osoby może dokonać określone grono osób np. rodzina, znajomi, współpracownicy ${ }^{19}$. Rozpoznawalność

15 J. Sieńczyło-Chlabicz, Rozpowszechnianie wizerunku osób powszechnie znanych, „Przegląd Prawa Handlowego” 2003, nr 9, s. 40; J. Bata, R. Markiewicz, Ochrona powszechnych..., w: Prawo mediów, op. cit., s. 18; A. Karpowicz, Jak reklamować się zgodnie z prawem, Warszawa 1997, s. 74. Por. także wyrok SA w Gdańsku z 21.06.1991 r. (I Acr 127/91 - opublik. OSA 1992, z. 1, poz. 8). Zdaniem J. Balcarczyk głos należy traktować jako odrębne od wizerunku dobro osobiste. Por. J. Balcarczyk, Prawo do wizerunku i jego komercjalizacja, Warszawa 2009, s. 54.

16 Ibidem, s. 54-55.

17 Por. orzeczenie SN z 27 lutego 2003 r., IV CKN 181/00 (OSP 2004, z. 6, poz. 75), wyrok SA w Łodzi z dnia 28 sierpnia 1996 r., I Acr 341/96, OSA 1997, z. 7-8, poz. 43 oraz glosa T. Grzeszczak, „Monitor Prawniczy” 1997, nr 8, poz. 318.

18 Ibidem; podobnie J. Błeszyński (glosa do wyroku SN z 27.02.2003, IV CKN 1819/00, OSP 2004, z. 6, poz. 75, s. 321; J. Balcarczyk, op. cit., s. 31 i n. Na szczególną uwagę zasługuje koncepcja J. Barty i R. Markiewicza wyróżniająca tzw. rozpoznawalność bezpośrednią i pośrednią tj. taki przypadek, gdy identyfikacja następuje na podstawie dołączonych do wizerunku wskazówek takich jak np. podpis. Patrz J. Barta, R. Markiewicz, Wokół prawa do wizerunku, „ZNUJ PWiOWI” 2002, z. 80, s. 13.

19 W tym kontekście na uwagę zasługuje teza zaprezentowana w wyroku SA w Warszawie z dnia 26 listopada 2003 r. VI ACa 348/03. Jak podkreślono, ,z art. 81 u.p.a.p.p. nie wynika, aby do naruszenia dóbr osobistych osoby, której wizerunek rozpowszechniono mogło dojść tylko wtedy, gdy wizerunek ten jest rozpoznawalny dla ogółu odbiorców. Artykuł 81 prawa autorskiego takich ograniczeń nie zawiera. Wręcz przeciwnie, właśnie rozpowszechnianie wizerunku osób powszechnie zna- 
zapewniona będzie także wówczas, jeżeli zamieszczony pod publikacją wizerunku tekst pomaga $\mathrm{w}$ identyfikacji. Powyższa teza znajduje potwierdzenie w stanowisku zaprezentowanym w wyroku Sądu Apelacyjnego w Warszawie z dnia 16 kwietnia 2010 r. $^{20}$, a mianowicie ,publikacja zdjęć, które nie stanowią wizerunku (podobizny) danej osoby, ale w powiązaniu z treścią artykułu umożliwiają jej rozpoznanie (identyfikację), stanowi naruszenie dóbr osobistych" ${ }^{\text {21 }}$.

Podmiotem prawa do wizerunku jest osoba fizyczna, która została na nim przedstawiona, w więc której wizerunek dotyczy. Może to być

nych nie wymaga zgody zainteresowanego, jeżeli wizerunek wykonano w związku z pełnieniem przez nią funkcji publicznych (art. 81 ustęp 2 pkt 1 prawa autorskiego). Powyższy pogląd został zaprezentowany na tle następującego stanu faktycznego. W dniu 1 października 1997 r. w wiadomościach, między godziną 19.30 a 20.00 TVP SA wyemitowała program informujący o fakcie wszczęcia przez Prokuraturę Wojewódzką śledztwa w sprawie śmierci w Areszcie Śledczym w Poznaniu jednego $\mathrm{z}$ aresztowanych. Podano krótką informację o podejrzeniu, że sprawcami śmierci więźnia mogli być funkcjonariusze więzienni. Ilustracją tekstu były zdjęcia Aresztu Śledczego w Poznaniu, wypowiedzi jednego z więźniów i dwóch funkcjonariuszy aresztu oraz wnętrze aresztu. Sporny fragment audycji dotyczy zdjęć pokazujących areszt. Budynek pokazany jest przez około 10 sekund, w jednym z dwunastu okien widoczna postać więźnia, z tym że od pierwszego momentu jej pokazania obraz jest oddalony, na końcu widać tylko okno”. Ibidem.

20 Por. wyrok Sądu Apelacyjnego w Warszawie z dnia 16 kwietnia 2010 r. I ACa 1100/09.

21 Stan faktyczny w tej sprawie przedstawiał się następująco. Powódka mieszkała w niewielkim mieście T. Na początku kwietnia 2006 r. małoletnia wówczas M. została zgwałcona przez swoich kolegów, którzy najpierw podstępem doprowadzili ją do stanu upojenia alkoholowego, a następnie wykorzystali seksualnie. W trakcie tego zdarzenia sprawcy sfotografowali powódkę telefonem komórkowym, bez jej wiedzy i woli, a następnie zdjęcia te rozsyłali wśród swoich kolegów za pośrednictwem internetu. O powyższym wiedziało wąskie grono osób. Mimo że informacja ta była znana wśród niektórych uczniów ze szkoły, do której uczęszczała M., nikt nie dawał jej tego odczuć. W dniu 9.06.2006 r. na łamach gazety „F.” ukazał się materiał prasowy. Obejmował artykuł zatytułowany Tak się bawia gimnazjaliści! T. uczniowie urzqdzili pijacka orgię, na której gwatcili koleżankę i dwa zdjęcia przedstawiające nagą M. w trakcie dokonywania wobec niej czynności seksualnych, które zajmowały ponad połowę powierzchni tego materiału. Na jednym z tych zdjęć, poza delikatnym zamazaniem linii piersi, widoczna była niemal cała sylwetka nagiej powódki (od kolan do głowy), a także fragment jej twarzy (usta i podbródek) oraz fryzura. Z podtytułu oraz treści artykułu dodatkowo wynikało, że przedstawioną na zdjęciach ofiarą przemocy seksualnej była 14-letnia uczennica T. gimnazjum. Opublikowane, fotografie i treść artykułu umożliwiały zidentyfikowanie M. przez osoby trzecie. 
zarówno osoba dorosła, jak i dziecko ${ }^{22}$. Podmiotem prawa do wizerunku nie może być natomiast osoba prawna ${ }^{23}$. Oczywiście podmiot taki może ubiegać się o ochronę innych dóbr osobistych. Na potwierdzenie tej tezy należy przywołać pogląd zaprezentowany w wyroku Sądu Najwyższego z 25 maja 1977 r. $^{24}$, a mianowicie ,nie stanowi wizerunku osoby prawnej wygląd jej siedziby czy jednostek wchodzących w skład jej organów".

Nie ma natomiast wspólności prawa do wizerunku, co wynika ze specyfiki dóbr osobistych ${ }^{25}$. Zatem w przypadku sfotografowanej grupy osób mamy do czynienia $\mathrm{z}$ wieloma wizerunkami i odrębnymi prawa$\mathrm{mi}^{26}$. Wspólne może być jedynie utrwalenie ${ }^{27}$.

Należy przy tym podkreślić, że ochrona wizerunku ma autonomiczny charakter wobec innych dóbr osobistych. Zakaz wykorzystania wizerunku jest zatem niezwiązany z kwestią, czy w ten sposób narusza się np. sferę prywatności, intymności lub cześć, a więc inne dobra osobiste, choć jednocześnie w przypadku wykonania utrwalenia wizerunku może dojść do naruszenie również tych dóbr ${ }^{28}$.

22 Na marginesie jedynie warto tu odnotować, że niekiedy odmawia się przyznania ochrony wizerunku nasciturusa, z uwagi na brak przesłanki rozpoznawalności. Wydaje się jednak, że takie uogólnienie jest nieuprawnione. Z pewnością coraz doskonalsza technika obrazowania płodu, ale także wiek nasciturusa powodować będzie, że również w tym przypadku można mówić o możliwości identyfikacji płodu. Tym bardziej, że przecież nasciturus zgodnie z polskim prawem ma warunkową zdolność prawną.

23 Zob. wyrok SN z 14.11.1986 r. II CR 295/86 - „dobra osobiste osób prawnych - to wartości niemajątkowe dzięki którym osoba prawna może funkcjonować zgodnie ze swym zakresem działań”. Z kolei w wyroku SN z 25.05.1977 r. I CR 159/77 podkreślono, że „Zgodnie z art. 43 k.c. przepisy o ochronie dóbr osobistych osób fizycznych stosuje się odpowiednio do osób prawnych [...] Odpowiednie stosowanie art. 23 k.c. wyłącza z zakresu tej ochrony takie jednak dobra osobiste człowieka, które w przypadku osoby prawnej w ogóle nie mogą być brane pod uwagę, jak np. [...] wizerunek". Zob. także J. Balcarczyk, op. cit., s. 90 i 93.

24 Wyrok SN - Izba Cywilna z 25.05.1977 r., sygn. akt ICR 159/77.

25 Choć niekiedy wyróżnia się tzw. wizerunek wspólny, tzn. przypadek, gdy wizerunek kilku osób funkcjonuje w świadomości społecznej łącznie. Patrz szerzej J. Barcarczyk, op. cit., s. 55-56.

26 W tym przypadku mówi się o tzw. wizerunku zbiorowym.

27 J. Sieńczyło-Chlabicz, Przedmiot..., op. cit., s. 22.

28 Przypomnieć w tym miejscu należy, że zgodnie $\mathrm{z}$ art. 23 k.c. dobra osobiste człowieka w tym wizerunek pozostają pod ochroną prawa cywilnego niezależnie od ochrony przewidzianej w innych przepisach. 
Warto również wspomnieć o zasadach wykonywania prawa do wizerunku. Zasadniczo może z tego uprawnienia skorzystać osoba przedstawiona na wizerunku, aczkolwiek można sobie wyobrazić sytuację, gdy takim uprawnieniem dysponować będzie inna osoba na podstawie zawartej umowy np. producent reality show wobec wizerunku osób uczestniczących w audycji. Innym podmiotem, który należy zaliczyć do kręgu osób uprawnionych do dysponowania prawem do wizerunku może być przedstawiciel ustawowy wobec nieposiadającej zdolności do czynności prawnej. Po śmierci - ochrona przez 20 lat (art. 83 pr.aut., ale kto?; analogia z art. 78 ust. 2 pr.aut.).

Ochrona wizerunku może być oparta na dwóch konstrukcjach, a mianowicie na podstawie przepisów o ochronie dóbr osobistych (art. 23 i 24 k.c.) jak również przepisów prawa autorskiego. Konstrukcja ochrony prawa do wizerunku oparta na art. 23 k.c. przesądza, że jest to prawo podmiotowe skuteczne erga omnes. Z kolei konstrukcja przewidziana $\mathrm{w}$ art. 81 ust. 1 pr.aut. opiera się na zagwarantowaniu wyłączności na wyrażenie zgody na rozpowszechnianie wizerunku. Warto tu wyjaśnić, że pod pojęciem rozpowszechniania należy rozumieć udostępnienie publicznie w jakikolwiek sposób. Jak z powyższego wynika, nie można zabronić samego utrwalania wizerunku. Natomiast można w sposób dowolny decydować o sposobie udostępnienia wizerunku np. poprzez przesądzenie, że ukaże się tylko w jednym tytule, w telewizji, w internecie lub w określonym kontekście. Ponadto powyższa regulacja gwarantuje prawo do integralności wizerunku, a więc nie można bez zgody osoby uprawnionej dokonywać fotomontażu np. zastąpienie naturalnego uzębienia sztucznie wybielonym. Można żądać wstrzymania rozpowszechniania wizerunku fałszywego. Warto podkreślić, że art. 81 nie wyłącza ochrony $\mathrm{z}$ art. 23 k.c. Jest to o tyle istotne, iż przypomnijmy, że w świetle rozwiązań kodeksowych istnieje domniemanie bezprawności działania, natomiast w przypadku konstrukcji wynikającej z prawa autorskiego będą obowiązywać normalne zasady rozkładu ciężaru dowodów. Ponadto zgodnie z art. 23 k.c. tego typu prawa osobiste są nieprzenoszalne, niedziedziczne i gasnące wraz ze śmiercią. Z kolei uprawnienie wynikające $\mathrm{z}$ art. 81 pr.aut. ma charakter majątkowy ${ }^{29}$. Należy odnotować

29 Podzielić należy pogląd, iż „Prawo do wizerunku” jest podmiotowym prawem osobistym. Należy ono do klasy praw podmiotowych bezwzględnych, a więc jest skuteczne wobec wszystkich (erga omnes) - poza podmiotem uprawnionym. Jest to prawo niemajątkowe, niezbywalne i niedziedziczne. Gaśnie więc wraz ze śmiercią 
koncepcję tzw. komercjalizacji wizerunku, wedle której wizerunek jest splotem dwóch praw podmiotowych, a mianowicie prawa osobistego (art. 23 k.c.) i majątkowego (art. 81 pr.aut.). Jak wyżej sygnalizowano, istnieje możliwość kumulatywnego lub alternatywnego stosowania obu konstrukcji. W wyroku SA w Krakowie z dnia 5 listopada 2002 r. podkreślono, że w przypadku publikacji zdjęć określonej osoby, do naruszenia dóbr osobistych może dojść już w przypadku umieszczenia wizerunku w określonym kontekście. W odniesieniu do tego dobra interesy powódki występują na innej „płaszczyźnie” niż ochrona jej wizerunku (która zapewnia autonomię decyzji osoby portretowanej). Umieszczenie jej zdjęcia w połączeniu z tekstem artykułu o prostytucji wywołuje sugestię, że jest ona osobą trudniącą się tą profesją. Kontekst publikacji zdjęcia powódki i wynikająca z niego sugestia stanowią dostateczną podstawę do przypisania pozwanym odpowiedzialności za zniesławienie powódki ${ }^{30}$.

podmiotu uprawnionego”. A. Matlak, Cywilnoprawna ochrona wizerunku, „Kwartalnik Prawa Prywatnego" 2004, nr 2, s. 320.

30 Por. wyrok SA w Krakowie z dnia 5 listopada 2002 r., sygn. akt I ACa $869 / 02$. Teza taka sformułowana została na podstawie następującego stanu faktycznego. Powódka występowała w 2000 r. w spektaklu pod tytułem Kurt Weil, czyli o samotności kobiet. Spektakl ten był przedstawiany kilkadziesiąt razy w różnych miejscowościach, przede wszystkim w Krakowie. Dla celów promocyjnych wykonano zestaw zdjęć z tego spektaklu, publikowanych w prasie i ogólnie dostępnych. Jedno z tych zdjęć przedstawia graną przez powódkę postać skąpo ubraną i w nieco prowokującej pozie. Zdjęcie to pozwani wykorzystali do ilustracji artykułu Mirosława K. o problemie prostytucji w Krakowie, opublikowanego w magazynie sobotnim „Gazety Krakowskiej”. Wprawdzie zdjęcie przedstawia graną przez powódkę postać ze spektaklu teatralnego, ale powódka jest na nim wyraźnie rozpoznawalna. W konsekwencji w odbiorze czytelników ,powódka może kojarzyć się z treścią artykułu o nocnym życiu Krakowa widzianym przez pryzmat osób trudniących się prostytucją. Tego rodzaju skojarzenia, czy wręcz traktowanie powódki jako osoby wykonującej ten zawód przez nieograniczoną ilość osób muszą być dla powódki bardzo przykre i poniżające". Publikacja zdjęcia powódki w „Gazecie Krakowskiej” w związku z artykułem pn. Nocne życie naruszyła nie tylko jej prawo do wizerunku, ale także jej dobre imię. W odniesieniu do tego dobra interesy powódki występują na innej „płaszczyźnie” niż ochrona jej wizerunku (która zapewnia autonomię decyzji osoby portretowanej). Umieszczenie jej zdjęcia w połączeniu z tekstem artykułu o prostytucji wywołuje sugestię, że jest ona osobą trudniącą się tą profesją. Kontekst publikacji zdjęcia powódki i wynikająca z niego sugestia stanowią dostateczną podstawę do przypisania pozwanym odpowiedzialności za zniesławienie powódki. Umieszczenie jej zdjęcia w połączeniu z tekstem artykułu o prostytucji wywołuje sugestię, że jest ona osobą trudniącą się tą profesją. Kontekst publikacji zdjęcia powódki i wynikająca z niego sugestia stanowią dosta- 
Kolejną istotną kwestią jest rozstrzygnięcie dylematu obecnego w debacie naukowej, a mianowicie czy wizerunek należy traktować na gruncie prawa autorskiego jak utwór. Pozytywne rozstrzygniecie tej kwestii otwiera bowiem dyskusję czy można stosować w drodze analogii np. przepisy o dozwolonym użytku z chronionych utworów, a więc chociażby uprawnienia przysługujące bibliotekom, archiwom, prawo cytatu, dozwolonego użytku prywatnego.

$\mathrm{Na}$ gruncie art. 81 prawa autorskiego warunkiem legalnego rozpowszechniania wizerunku jest uzyskanie zezwolenia osoby przedstawionej, ewentualnie przekazanie zapłaty za pozowanie, chyba że wyraźnie zastrzeżono coś innego ${ }^{31}$. Ważną kwestią jest zakres udzielonej zgody, ponadto zgoda musi być wyrażona świadomie co do jej konsekwencji ${ }^{32}$. Zgodzić należy się z teza, że „zezwolenie na rozpowszechnianie wizerunku może być udzielone w dowolnej formie, ale zgoda musi być zawsze niewątpliwa. Nie wystarczy przekonanie osoby wykorzystującej wizerunek np. dziennikarza, że skoro prowadził z zainteresowanym rozmowę i przedstawił się służbowo, to powinien domyślać się, że jego zdjęcie zostanie wykorzystane. Przeciwne zachowanie pozostaje w oczywistej sprzeczności z art. 81 ustawy o prawie autorskim, "33. Jak wyjaśniono

teczną podstawę do przypisania pozwanym odpowiedzialności za zniesławienie powódki.

31 Ż. Cołoszyńska, Prawne aspekty ochrony wizerunku, „Prokurator” 2010, nr 4, 2011, nr 5, s. 10.

${ }^{32}$ Zob. także wyrok SA w Krakowie z 20.07.2004 r. I ACa 564/04. Zamieszczenie na stronie portalu internetowego tzw. głębokiego linku (deep link) umożliwiającego użytkownikom tego portalu bezpośrednie (tj. z pominięciem struktury nawigacyjnej strony głównej innego portalu) otwarcie rekomendowanej witryny stanowi rozpowszechnianie wizerunku zamieszczonego na tej witrynie strona pozwana jako wydawca portalu internetowego SECUNDA zamieściła $\mathrm{w}$ dniu 2 września 2002 r. na stronach tego portalu w dziale „Erotyka i seks” w rubryce „Nagrodzone strony” pod nazwą „Młode kobiety są najlepsze” odesłanie (link) do strony: www.mlode-dupy.w.tertia.pl. Strona ta została opisana przez wydawcę portalu Secunda następująco: „10 galerii zdjęć hardcore. Stanowczo można było sobie gorzej poradzić z tym tematem". W galerii $\mathrm{nr} 3$ opublikowano zdjęcie powódki w stroju kapielowym, wykonane podczas sesji fotograficznej, towarzyszącej naborowi kandydatek do kampanii reklamowej w czasie, gdy powódka współpracowała z agencją modelek „R...”. Powódka nigdy nie wyrażała zgody na rozpowszechnianie tego zdjęcia ani też nie otrzymała wynagrodzenia za udział w sesji fotograficznej. Dlatego też Sąd uznał, że doszło do naruszenia prawa do wizerunku.

33 Por. wyrok SA we Wrocławiu z 18.6.2009 r. I ACa 459/09. Stan faktyczny przedstawiał się następująco. W wydaniu „G. W.” ukazał się artykuł pt. Figiel eks- 
z kolei w wyroku Sądu Apelacyjnego w Krakowie z dnia 19 grudnia 2001 r. przepisy art. 81 pr.aut. chronią wyłączną kompetencję osoby portretowanej do decydowania o rozpowszechnianiu jej wizerunku. Dobrem chronionym jest autonomia każdej osoby w zakresie swobodnego rozstrzygania, czy i w jakich okolicznościach jej wizerunek może być rozpowszechniony. Osoba przedstawiona na zdjęciu fotograficznym (lub innym materialnym nośniku jej wizerunku) może dowolnie ograniczyć zakres zezwolenia na jego rozpowszechnianie: zezwolić na publikację tylko w oznaczonym czasopiśmie i/lub tylko w związku z oznaczonymi okolicznościami (np. w związku z określonym tekstem artykułu prasowego), wyznaczyć granice czasowe publikacji itp. ${ }^{34}$

Nie ma natomiast konieczności uzyskania zgody w dwóch sytuacjach. Po pierwsze wówczas jeżeli wizerunek stanowi jedynie szczegół pewnej całości, takiej jak zgromadzenie, krajobraz, publiczna impreza.

perta autorki Marleny M., w którym powodowi przypisano zamiar wpłynięcia na wynik procesu karnego przeciwko osobie, która zabrała w celu przywłaszczenia fragment balustrady z pałacu w Sz. G., poprzez wydanie na potrzeby oskarżonego opinii, w której powód odmówił skradzionemu przedmiotowi „,wartości dla kultury”. Odnośnie użytych zdjęć, to jak przyznała autorka artykułu pochodziły one z archiwum redakcji i zostały zrobione $\mathrm{w}$ innych okolicznościach. Zezwolenie na rozpowszechnianie wizerunku może być udzielone w dowolnej formie, ale zgoda musi być zawsze niewątpliwa. Na umieszczenie tychże zdjęć powód nie wyraził zgody i nie był o to pytany. Nie wystarcza tu przekonanie dziennikarki, że skoro prowadziła z powodem rozmowę i przedstawiła się służbowo, to powinien domyślać się, że jego zdjęcie zostanie wykorzystane. Pozostaje to w oczywistej sprzeczności z powołanym przepisem art. 81 ustawy o prawie autorskim.

34 Zob. wyrok SA w Krakowie z dnia 19 grudnia 2001 r., sygn. akt I ACa 957/01. Otóż w miesięczniku „Hustler” zostało zamieszczone zdjęcie powódki w towarzystwie sześciu mężczyzn; zdjęcie to zostało wykonane podczas realizacji w Pradze filmu o czeskim fotografiku - Janie Saudku; powódka była współreżyserem i tłumaczem na planie tego filmu; ekipę filmowa, która pozowała Janowi Saudkowi sfotografował również Bogdan K.; zdjęcia te miały stanowić ilustrację pomysłu artystycznego J. Saudka i pozostać w posiadaniu powodów; powódka nie wyrażała zgody na ich publikację; zamieszczenie zdjęcia w miesięczniku „Hustler” bez podania źródła jego pochodzenia oraz okoliczności, w jakich zostało zrobione sugeruje, że powódka pozowała nago, świadoma tego, że stanie się ono ilustracją do artykułu p.n. Jazda próbna na kobiecie. Przekazanie zapłaty za pozowanie: Nie jest samo $\mathrm{w}$ sobie równoznaczne $\mathrm{z}$ upoważnieniem do eksploatacji wizerunku na wszystkie sposoby. Osoba powszechnie znana nie wymaga uzyskania zgody, rozpowszechnienie wizerunku osoby powszechnie znanej, jeżeli wizerunek wykonano w związku z pełnieniem przez nią funkcji publicznych (w szczególności politycznych, społecznych, zawodowych). 
Trzeba tu wyraźnie zaznaczyć, że powyższa uwaga nie będzie dotyczyć przypadku, gdy wizerunek wykonano w miejscu publicznym. Jak wyjaśniono w wyroku Sądu Apelacyjnego w Krakowie z 19.12.2001 r. ${ }^{35}$ „,chodzi o sytuacje, których wizerunek osoby pełni podporządkowaną rolę, jest elementem akcydentalnym lub akcesoryjnym przedstawianej całości, przez co jego usunięcie nie pozbawiłoby zdjęcia (rysunku, malowidła) znaczenia i treści, nie zmieniłoby jego charakteru"36. A zatem przedstawienie całej lub fragmentu publiczność np. na stadionie będzie dopuszczalne, ale poszczególna osoba w tym samym miejscu już nie, choć prezentowany jest pogląd, że każdy kto przychodzi na stadion musi się z tym liczyć.

Po drugie nie ma konieczności uzyskania zgody w przypadku zamiaru rozpowszechniania wizerunku osoby powszechnie znanej, jeżeli wykonano go w związku z pełnieniem przez tę osobę funkcji publicznych, w szczególności politycznych, społecznych, zawodowych ${ }^{37}$. Co istotne, brak obecnie w pr.aut. definicji ustawowej „osoby powszechnie znanej” oraz „pełniącej funkcje publiczne”. Pojęcia te budzą wątpliwości. Ze-

35 Wyrok Sądu Apelacyjnego w Krakowie z 19.12.2001 r., sygn. akt I Aca 957/01. 36 Ibidem.

37 Na marginesie warto odnotować, że szczególna sytuacja dotyczy uzyskiwania zgody sportowca, będącego reprezentantem Polski. Otóż zgodnie z art. 14 ustawy z dnia 25 czerwca 2010 r. o sporcie (Dz. U. 2010, Nr 127, poz. 854, poz. 857 z późn. zm.), członek kadry narodowej ma obowiązek udostępnić, na zasadach wyłączności, swój wizerunek w stroju reprezentacji kraju polskiemu związkowi sportowemu, który jest uprawniony do wykorzystania tego wizerunku do swoich celów gospodarczych w zakresie wyznaczonym przez regulaminy tego związku lub międzynarodowej organizacji sportowej działającej w danym sporcie. W przypadku reprezentanta - członka ekipy olimpijskiej, udostępnienia również na zasadach wyłączności na rzecz Polskiego Komitetu Olimpijskiego, który jest uprawniony do wykorzystania tego wizerunku do swoich celów gospodarczych w zakresie wyznaczonym przez swoje regulaminy lub regulaminy Międzynarodowego Komitetu Olimpijskiego. Ponadto w myśl postanowień tego przepisu, zawodnik przed zakwalifikowaniem do kadry narodowej lub reprezentacji olimpijskiej wyraża zgodę na rozpowszechnianie swojego wizerunku w stroju reprezentacji kraju w rozumieniu art. 81 ust. 1 pr.aut. Patrz szerzej M. Badura, H. Basiński, G. Kałużny, M. Wojcieszak, Komentarz do art. 14 ustawy o sporcie, LEX 2011; R. Szczepaniak, Problem prawa do wizerunku sportowca - reprezentanta kraju, M. Praw. 2007, nr 17, s. 948-956; D. Flisak, Zgoda kadrowicza na rozpowszechnienie wizerunku, „Rzeczpospolita”, 19 maja 2009; J. Balcarczyk, Prawo do sportowego wizerunku w ujęciu prawa polskiego, w: Współczesne problemy prawa prywatnego. Księga pamiatkowa ku czci profesora Edwarda Gniewka, red. J. Gołaczyński, P. Machnikowski, Warszawa 2010, s. 2-5; D. Bunikowski, Prawo do wizerunku sportowca, ,Jurysta” 2007, nr 5, s. 23. 
zwolenie na rozpowszechnianie wizerunku takich osób ma służyć przede wszystkim celom informacyjnym (ewentualnie wyjaśnianiu, krytyce - np. wizerunek polityka obrazujący tekst prasowy, wizerunek na okładce zapowiadający tekst wewnątrz numeru), a w pewnych okolicznościach także swoboda twórczości (np. wizerunek polityka zastosowany w satyrze). W tym kontekście na uwagę zasługuje wyrok Sądu Najwyższego z dnia 14.12.2011 r. dotyczący sprawy popularnego aktora ${ }^{38}$. W tym przypadku SN stwierdził, że publiczny - w przyjętym wyżej rozumieniu - status tych osób nie powoduje jednak, że ich życie prywatne staje się automatycznie „,̇yciem publicznym”. Może być ono przedmiotem zawężonej ochrony prawnej jedynie w granicach, jakie wyznacza konieczna na to zgoda zainteresowanej osoby. Prawo prasowe i prawo autorskie uzależniają co do zasady możliwość rozpowszechniania wizerunku oraz publikowania informacji dotyczących prywatnej sfery życia od zgody osoby zainteresowanej. Zgoda uprawnionego stanowi przyczynę wyłączająca bezprawność naruszenia dobra osobistego w postaci prywatności na gruncie art. 23 i 24 k.c. Istnienia zgody uprawnionego, ani też jej zakresu nie domniemywa się. Pozwanego zaś obciąża obowiązek wykazania, że uzyskał zgodę uprawnionego na rozpowszechnianie informacji dotyczącej jego życia prywatnego lub rozpowszechniania wizerunku na określonych warunkach $^{39}$. Jak podkreślono, strona pozwana nie wykazała na czym miałby polegać związek między relacją osobistą powoda i Edyty Z. a jego działalnością publiczną.

Podobną kwestię rozważał Sąd Najwyższy w sprawie zakończonej wyrokiem z 24.01.2008 r. I CSK 341/07 Anna M. v. GCF ${ }^{40}$. Otóż także w tym przypadku ustalono, że materiał dotyczył powódki Anna M., znanej aktorki, a artykuł zawierał informacje dotyczące wakacyjnego pobytu powódki w E., natomiast na okładce i wewnątrz numeru zamieszczone zostały zdjęcia przedstawiające powódkę topless. Z kolei w innym numerze tego pisma opublikowany został artykuł związany z osobą Kuby W., w którym padło także nazwisko powódki. W kolejnym numerze za-

38 Zob. wyrok Sądu Najwyższego z dnia 14.12.2011 r., sygn. akt I CSK 111/11. Stan faktyczny przedstawiał się w tym przypadku następująco. Otóż w 2008 r. serwisie internetowym pudelek ukazały się artykuły dotyczące powoda Cezarego P. i Edyty Z. Publikacje te zawierały informacje dotyczące związku powoda z Edytą Z., fotografie powoda $\mathrm{z}$ Edytą Z., zdjęcia domu powoda.

39 Por. także wyrok SN z dnia 20 maja 2004 r., II CK 330/03 - niepublikowany.

40 Wyrok Sądu Najwyższego z 24.1.2008 r., sygn. akt I CSK 341/07, Anna M. v. GCF. 
mieszczono, na okładce i wewnątrz numeru, zdjęcia powódki oraz opublikowano krótki artykuł informujący, że zadebiutowała ona w sztuce teatralnej. Ukazał się także artykuł zatytułowany Aktorka chce być radnq stolicy; na okładce i wewnątrz numeru zamieszczone zostały zdjęcia z wizerunkiem powódki. Także w kolejnych numerach gazety „G.C.F.” zamieszczane były zdjęcia $\mathrm{z}$ wizerunkiem powódki oraz związane z jej osobą artykuły. Sąd Najwyższy przypomniał w uzasadnieniu swego rozstrzygnięcia, że ,przepis art. 14 ust. 6 prawa prasowego wyłącza warunek zgody osoby zainteresowanej na publikację informacji oraz danych dotyczących prywatnej sfery życia, jeżeli wiąże się to bezpośrednio z działalnością publiczną danej osoby. Podobnie zezwolenia nie wymaga - zgodnie z art. 81 ust. 1 pkt 2 pr.aut. - rozpowszechnianie wizerun$\mathrm{ku}$ osoby powszechnie znanej, jeżeli wizerunek wykonano w związku z pełnieniem przez nią funkcji publicznych, w szczególności politycznych, społecznych i zawodowych" "41. Stąd też podkreślono, że pojęcie „działalności publicznej” przewidziane w art. 14 ust. 6 pr.pras. należy rozumieć szeroko, podobnie jak w regulacji odnoszącej się do wizerunku (tj. art. 81 ust. 2 pkt 1 pr.aut.) przyjmując, że nie chodzi tu jedynie o działalność polityczną ${ }^{42}$. SN wskazał, że „osobami prowadzącymi działalność publiczną w rozumieniu tego przepisu mogą być, w określonych okolicznościach, także inne osoby, spoza kręgów polityki, działające - także w formach niezinstytucjonalizowanych - w dziedzinie nauki lub sztuki, których postawa i głoszone poglądy współkształtują poglądy panujące w społeczeństwie i które skupiają wokół siebie znaczące środowiska opiniotwórcze, przez które mogą wywierać istotny wpływ na bieg spraw publicznych" "43. Co należy szczególnie podkreślić, Sąd wskazał różnice zakresowe pojęcia „osoby publicznej” i „osoby prowadzącej działalność publiczną”. Otóż jak wyjaśniono, „osobą publiczną” w szerokim rozumieniu, jest „osoba znana publicznie z racji różnych form swojej aktywności, rozpoznawalna w szerokich kręgach społeczeństwa”,44. Z kolei według tego stanowiska „osobą prowadzącą działalność publiczną jest natomiast osoba - niekoniecznie szerzej publicznie znana - prowadząca działalność związaną z różnymi instytucjami życia publicznego

41 Ibidem.

42 SN powołał się w uzasadnieniu na inne orzeczenie, a mianowicie wyrok Sądu Najwyższego z dnia 12 września 2001 r., II CKN 559/99.

43 Zob. uzasadnienie wyrok SN z 24.01.2008 r., sygn. akt I CSK 341/07.

44 Ibidem. 
i społecznego, w której realizuje się interes publiczny. [...] Do kategorii osób publicznych należą zarówno osoby sprawujące funkcje publiczne, jak i osoby, które nie pełniąc ich, odgrywają rolę w różnych dziedzinach życia publicznego, takich jak polityka, życie społeczne, kultura i sztuka, a pośród nich aktywni w tych dziedzinach, cieszący się znacznym zainteresowaniem publiczności i mediów, artyści i gwiazdy rozrywki. Osoby te nierzadko same zabiegają o popularność, będącą dla nich miarą powodzenia zawodowego, także przez udzielanie wywiadów i informacji o swoim życiu prywatnym wielonakładowym gazetom o niskich czasem aspiracjach" "45. Jednocześnie SN zauważył, że nie można pomijać, iż przez opisane działania, prowokujące zainteresowanie mediów, osoby takie dobrowolnie pozbawiają się części swojej prywatności, przez co - co najmniej w sposób dorozumiany - udzielają zgody na informowanie o ich życiu osobistym. Taka zgoda nie może być jednak utożsamiana z udzieleniem zezwolenia na ujawnianie wszystkich faktów należących do sfery ich życia prywatnego, udzielenie zgody w tej postaci i ewentualny jej zakres podlegają ustaleniu na podstawie zindywidualizowanych okoliczności danej sprawy. Okoliczności, z których pozwani wywodzili udzielnie przez powódkę zgody na informowanie przez media bez ograniczeń o jej życiu osobistym, nie zostały przez nich dowiedzione. Pozwani nie wykazali faktu udostępniania przez powódkę swojej prywatności mediom przez liczne wywiady i wypowiedzi dotyczące jej życia osobistego, a fakt wykonywania przez powódkę zawodu aktorki traktowali jako drugoplanowy, eksponując jej status jako tzw. celebrytki, tj. osoby sławnej, pojawiającej się często w środkach masowego przekazu, utrzymującej się z podtrzymywania zainteresowania mediów swoją osobą której publiczne postawy i wypowiedzi mają wpływ na opinię publiczną. Sąd Najwyższy podkreślił, że ,status ten równoznaczny jest z kwalifikacją określonej osoby jako osoby publicznej, a w ujęciu art. 81 ust. 2 pkt 1 pr.aut. osoby powszechnie znanej. [...] Zgodnie z art. 81 ust. 2 pr.aut. i art. 14 ust. 6 pr.pras. konieczne jest wykazanie związku pomiędzy wykonywaną działalnością publiczną a opublikowanym wizerunkiem lub informacją o prywatnym charakterze. Musi więc istnieć zależność między zachowaniem danej osoby w sferze publicznej a jej zachowa-

45 Ibidem. Według stanowiska zaprezentowanego w wyroku Sądu Najwyższego z dnia 12 września 2001 r., II CKN 559/99, działalnością publiczną może być np. pełnienie funkcji prezesa lokalnej spółdzielni mieszkaniowej. 
niem w sferze prywatnej, co w okolicznościach sprawy nie zostało przez pozwanych wykazane" ${ }^{\text {"46 }}$.

$\mathrm{W}$ innej sprawie dotyczącej publikacji zamieszczonej w tabloidzie ${ }^{47}$, analizie poddano następujący stan faktyczny. Otóż w dniu 28 kwietnia 2006 r. w dzienniku „F.” ukazał się artykuł autorstwa M., publikującej pod pseudonimem X., pt. Ksiadz bawi się z kochanka, w którym zostały zawarte nieprawdziwe treści odnośnie domniemanego romansu powoda, będącego księdzem, z powódką, pozostającą wówczas w związku małżeńskim. W artykule przedstawiono historię rzekomo potajemnych spotkań tych osób, a jako ilustrację przedstawiono zdjęcia prezentujące przyjęcie sylwestrowe z udziałem wielu osób. W rzeczywistości - jak ustalił Sąd - powodów łączyła zażyła przyjaźń, A. i B. uczestniczyli w przyjęciach i imprezach okolicznościowych z udziałem innych osób, razem tańczyli. Co jednak znacznie istotniejsze z punktu widzenia omawianej tu problematyki, pozwana redakcja nie wykazała należycie, aby zachodziły określone w art. 81 prawa autorskiego okoliczności zezwalające na publikację wizerunku powodów. Stąd też zdaniem Sądu doszło do naruszenia dóbr osobistych powodów w postaci prawa do wizerunku. Jak wyjaśniono, wizerunek człowieka jest, zgodnie z art. 23 k.c. zaliczany do jego dóbr osobistych podlegających ochronie niezależnie od tego, czy wskutek posłużenia się nim w sposób bezprawny, a więc bez zgody zainteresowanego, przez osobę trzecią doszło do naruszenia innych dóbr osobistych powoda, jak cześć czy godność. Zakres ochrony wizerunku człowieka w sposób szczegółowy określa art. 81 prawa autorskiego, który stanowi, że rozpowszechnianie wizerunku wymaga zgody osoby na nim przedstawionej. Pozwani nie wykazali, aby powodowie wyrazili zgodę na opublikowanie zdjęć ilustrujących przedmiotowy artykuł, nie zachodzą zaś wskazane w art. 81 ust. 2 pkt 2 okoliczności, w których uzyskanie zezwolenia nie jest wymagane, a więc rozpowszechnianie wizerunku osoby stanowiącej jedynie szczegół całości takiej jak zgromadzenie,

46 Ibidem. Sąd podkreślił nadto, że dostęp do prywatności tych osób, poza ich zgodą, wynika z tego, że prowadzą działalność publiczną (argument z art. 14 ust. 6 pr.pras.) lub pełnią funkcję publiczną (art. 81 ust. 2 pkt 2 pr.aut.), które z racji zaangażowania interesu ogólnego powinny podlegać społecznemu osądowi czy wręcz kontroli. Powódka nie zajmowała żadnej publicznie ogłaszanej postawy w istotnych kwestiach społecznych, poza udziałem w kampanii reklamowej i publicznej dyskusji na temat środków antykoncepcyjnych, które jednak nie były związane tematycznie z przedmiotowymi publikacjami.

47 Wyrok SA W-wa z 10.6.2008 r. VI ACa 1648/07. 
krajobraz, publiczna impreza. Co istotne, podkreślono, że powódka A. może być uznana za osobę wykonującą działalność publiczną jako pracownik Urzędu Miasta i Gminy Z. pełniący funkcję podinspektora ds. nadzoru nad majątkiem, tym niemniej nie ma żadnej zależności między jej zachowaniem w sferze działalności publicznej a opisanymi w artykule zachowaniami w sferze prywatnej, Nieco inaczej Sąd ocenił sytuację powoda B., który jako ksiądz, przewodnik duchowy, powinien swoim życiem potwierdzać wartości podzielane przez większość obywateli, zatem zarówno jego działalność publiczna, jak i życie prywatne może podlegać ocenie w aspekcie religijnym, etycznym czy moralnym. Takiej ocenie podlega każda osoba, której publiczna działalność wiąże się z prezentacją określonych wartości, np. lekarz, nauczyciel, sędzia czy adwokat, zaś prawo do oceny w świetle wyznawanej religii czy ogólnie pojętych wartości moralnych powszechnie akceptowanych, niezależnie od wyznawanego światopoglądu, wynika z preambuły Konstytucji Rzeczypospolitej Polskiej odwołującej się do uniwersalnych wartości wynikających zarówno z wiary w Boga, jak i z innych źródeł.

Z kolei w wyroku SN z 11.04.2006 r. I CSK $159 / 05^{48}$ fakt, bezprawnego wykorzystania wizerunku pokrzywdzonych i podania do publicznej wiadomości nieprawdziwej informacji z ich życia intymnego do związanej z niemałymi kosztami reklamy czasopisma, której celem było zwiększenie korzyści majątkowej, której przysparza jego wydawanie, nie jest obojętny dla ustalenia wysokości zadośćuczynienia pieniężnego należnego pokrzywdzonym, wobec czego zadośćuczynienie to powinno być „odpowiednio” wyższe.

W kolejnej analizowanej sprawie ustalono, że na okładce numeru 3 tygodnika z dnia 17 stycznia 2002 r. zamieszczone zostało, zajmujące niemal całą okładkę, zdjęcie powodów zaopatrzone tytułem Ślub już wkrótce? Mateusz K. będzie ojcem! Wewnątrz numeru, na stronach 4 i 5 zamieszczono artykuł pt. Mateusz K. i Agnieszka G. Dziecko w drodze. Czy teraz zdecyduja się na ślub? Artykuł został zilustrowany czterema zdjęciami powodów, w tym tylko jedno dotyczyło sfery życia powoda jako osoby publicznej. Jedno ze zdjęć przedstawiało powodów w otoczeniu rodziny powódki i błędnie zostało opisane jako przedstawiające powodów z rodziną Mateusza K. W artykule skomentowano szerzej informację o tym, że powodowie spodziewają się dziecka. Opublikowane

48 Por. wyrok SN z 11.04.2006 r. I CSK 159/05. 
zdjęcia pochodziły z lat 1996-1997. Pozwani nie mieli zgody powodów na publikację ich wizerunku. Nie miał on związku z ich działalności powszechnie znaną - powoda jako sportowca, powódki jako jego wieloletniego menadżera. Informacja o oczekiwaniu narodzin dziecka była nieprawdziwa. Okładka tygodnika, jako jego reklama, czternaście razy ukazała się w programach telewizyjnych stacji TVP, TVN i Polsat.

Jeszcze innym zagadnieniem, jest kwestia osób towarzyszących, które nie mają statusu osób publicznych. W szczególności dotyczyć to może małoletnich dzieci, małżonków lub partnerów życiowych. Analizując przesłanki ustawowe, należy kategorycznie stwierdzić, że w tym przypadku bez zgody tych osób nie należy rozpowszechniać ich wizerunku. Na uwagę zasługuje także teza zaprezentowana w wyroku SN z dnia 12.9.2007 r. ${ }^{49}$, a mianowicie, iż informacje dotyczące kwestii związanych z przyjściem na świat dziecka osób prowadzących działalność publiczną, nie mogą być uznane za pozostające w sferze działalności publicznej lub z nią związanej ${ }^{50}$.

Na koniec warto jedynie wspomnieć, o wprowadzonej niedawno penalizacji zachowań polegających na utrwalaniu wizerunku nagiej osoby lub osoby w trakcie czynności seksualnej, jeżeli sprawca używa w tym celu przemocy, groźby bezprawnej lub podstępu, jak również na rozpowszechnianiu bez zgody wizerunku nagiej osoby lub osoby w trakcie czynności seksualnej ${ }^{51}$.

49 Wyrok SN z 12.9.2007 r. I CSK 191/07.

50 Sąd ten ustalił w tej sprawie, że w marcu i kwietniu 2004 r. na łamach Dziennika zostało opublikowanych kilka artykułów, w których zamieszczono informacje dotyczące porodu powódki w szpitalu $\mathrm{w}$ Ł., z podaniem, że miało miejsce cesarskie cięcie, jej odwiedzin w szpitalu przez pozwanego, sposobu opuszczenia szpitala przez powódkę. W publikacjach tych zamieszczono także informacje o miejscu zamieszkania powoda, sugerowano, że powódka paliła w szpitalu papierosy, wyrzuciła księdza i odmówiła przyjęcia komunii, gdyż nie jest katoliczką, powódka może mieć problemy $\mathrm{z}$ nadaniem imienia synowi, a jej ojciec nie zobaczy szybko wnuka, bowiem przebywa w zakładzie karnym. Sąd Okręgowy stwierdził również, że powódka od drugiego dnia pobytu w szpitalu nie opuszczała pokoju, do którego drzwi były zamknięte, a okna zasłonięte żaluzjami, gdyż fotoreporterzy, w tym Dziennika, próbowali zdobyć informacje o powódce i w tym celu stale obserwowali pokój, w którym przebywała powódka, próbowali się do niej dostać, rozpytywali personel szpitala, obserwowali powoda, kiedy przyjeżdżał w odwiedziny. Publikacje były opatrzone zdjęciami powodów, także $\mathrm{z}$ okresu poprzedzającego pobyt powódki w szpitalu, w tym z okresu jej dzieciństwa.

51 Tak art. 191a $\S 1$ k.k. przewidujący karę pozbawienia wolności od 3 miesięcy do lat 5. Patrz szerzej B. Filek, Wizerunek nagiej osoby jako znamię przestępstwa 
Sukces i popularność tabloidów oraz zjawisko tabloidazacji mediów, łączy się z masowym wykorzystaniem wizerunków bohaterów materiałów prasowych. Jest to obecnie tym bardziej ułatwione, że w dobie ery cyfrowej, utrwalenie wizerunku w postaci i jakości umożliwiającej publikowanie w mediach, może być dokonane praktycznie przez każdego, na różnych często miniaturowych urządzeniach elektronicznych. Choć oczywiście zwiększony popyt na tego typu materiały powoduje, iż ukształtował się wręcz odrębny zawód fotoreportera (tj. paparazzi). Masowość tego rodzaju praktyk nie oznacza, iż może być przyzwolenie na działalność niezgodną z prawem. Jak wynika z zaprezentowanych przykładów, instrumenty ochrony wizerunku są dostępne i mogą być skuteczne, choć wymagają podjęcia wyżej wskazanych kroków prawnych. Trzeba jednak przyznać, że z pewnością sukces tego rodzaju aktywności prasowych, jest odpowiedzią na zapotrzebowanie rynku. Stąd też spodziewać można się rosnącej ilości naruszeń, choć z drugiej strony wydaje się, że wyżej zaprezentowane instytucje prawne mogą być skutecznym środkiem prewencji generalnej.

\section{Image protection at the time of media tabloidization}

\section{Summary}

Examining modern media markets, one notices a common phenomenon of the predominance of tabloids, which are successful both in terms of readership and economic results. It is most likely the effectiveness and economic efficiency of what these media offer that results in a broader process of all media, whether printed or electronic, 'contracting the tabloid virus'. This is the context within which media tabloidization is discussed, in the sense of the transformation of traditional, 'noble' media formats into social media, characterized by the prevalence of topics that arouse widespread interest (entertainment, celebrity scandals), shocking through sex and violence, and abounding in pictures, which is particularly significant from the point of view of this study. Additionally, press materials are shorter, which typically results in the simplified description of events, frequently violating the principles of good taste. The aim of this study is to suggest legal regulations on the matter of image protection in the context of media tabloidization.

z art. 191 a 1 k.k., „Prok. i Pr.” 2012, nr 7-8, s. 61 i n.; R. Krajewski, Przestepstwo utrwalania i rozpowszechniania wizerunku nagiej osoby lub osoby w trakcie czynności seksualnej, „Prok. i Pr.” 2012, nr 5, s. 20; M. Mozgawa, Komentarz do art. 191 a k.k., w: Komentarz do Kodeksu karnego, red. idem, LEX 2013; A. Marek, Komentarz do art. 191a k.k., LEX 2010. 